\title{
A Review of SWAT Model Application in Africa
}

\author{
George Akoko ${ }^{1}$ (D) Tu Hoang Le ${ }^{2}$, Takashi Gomi ${ }^{3,4}$ and Tasuku Kato ${ }^{3,4, *}$ \\ 1 Department of Agriculture and Environment Engineering, United Graduate School of Agriculture, \\ Tokyo University of Agriculture and Technology, Tokyo 183-8538, Japan; georgeakoko88@gmail.com \\ 2 Research Center for Climate Change, Nong Lam University HCMC, Ho Chi Minh City 700000, Vietnam; \\ tu.lehoang@hcmuaf.edu.vn \\ 3 Graduate School of Institute of Agriculture, Tokyo University of Agriculture and Technology, \\ Tokyo 183-8538, Japan; gomit@cc.tuat.ac.jp \\ 4 Institute of Global Innovation Research, Tokyo University of Agriculture and Technology, Fuchu, \\ Tokyo 183-8538, Japan \\ * Correspondence: taskkato@cc.tuat.ac.jp
}

\section{check for}

updates

Citation: Akoko, G.; Le, T.H.; Gomi, T.; Kato, T. A Review of SWAT Model Application in Africa. Water 2021, 13, 1313. https://doi.org/10.3390/ w13091313

Academic Editor: Viktor O Polyakov

Received: 10 March 2021

Accepted: 4 May 2021

Published: 8 May 2021

Publisher's Note: MDPI stays neutral with regard to jurisdictional claims in published maps and institutional affiliations.

Copyright: (C) 2021 by the authors. Licensee MDPI, Basel, Switzerland. This article is an open access article distributed under the terms and conditions of the Creative Commons Attribution (CC BY) license (https:/ / creativecommons.org/licenses/by/ $4.0 /)$.
Abstract: The soil and water assessment tool (SWAT) is a well-known hydrological modeling tool that has been applied in various hydrologic and environmental simulations. A total of 206 studies over a 15-year period (2005-2019) were identified from various peer-reviewed scientific journals listed on the SWAT website database, which is supported by the Centre for Agricultural and Rural Development (CARD). These studies were categorized into five areas, namely applications considering: water resources and streamflow, erosion and sedimentation, land-use management and agricultural-related contexts, climate-change contexts, and model parameterization and dataset inputs. Water resources studies were applied to understand hydrological processes and responses in various river basins. Land-use and agriculture-related context studies mainly analyzed impacts and mitigation measures on the environment and provided insights into better environmental management. Erosion and sedimentation studies using the SWAT model were done to quantify sediment yield and evaluate soil conservation measures. Climate-change context studies mainly demonstrated streamflow sensitivity to weather changes. The model parameterization studies highlighted parameter selection in streamflow analysis, model improvements, and basin scale calibrations. Dataset inputs mainly compared simulations with rain-gauge and global rainfall data sources. The challenges and advantages of the SWAT model's applications, which range from data availability and prediction uncertainties to the model's capability in various applications, are highlighted. Discussions on considerations for future simulations such as data sharing, and potential for better future analysis are also highlighted. Increased efforts in local data availability and a multidimensional approach in future simulations are recommended.

Keywords: SWAT model; Africa; review; applications; challenges

\section{Introduction}

Hydrological and related water-assessment simulations have been widely used in addressing a broad spectrum of water-resources challenges globally. The assessments have mainly been done using computer models, which offer advantages for economic savings, since they are capable of representing processes that occur in the real world in space and time. Besides this, they are used to increase our understanding of various physical processes and obtain quantitative estimates of water distribution in various environmental areas. The development of hydrologic models and recent advances in the use of geographic information systems (GIS), have made a good alternative approach for water resources and environmental assessment. Thus, they have been increasingly applied to evaluate water resources in recent decades [1,2].

The soil and water assessment tool (SWAT) is widely recognized as one of the top hydrological models applied in addressing hydrologic and environmental issues across 
the globe. The SWAT model is a physically based, semi-distributed, and continuoustime hydrological model [3]. The model was developed to assess water resources and predict the impacts of land use/cover changes, land management practices on soil erosion, sedimentation and non-point source pollution on watersheds or large river basins [4].

There have been many applications of the SWAT model regarding water resources and related environmental assessments in Africa since the 2000s [5]. The model has been applied in categories such as land use change, climate change, erosion, model development and water quality [6]. In addition, it has also been applied in categories such as curve number modifications, wetland applications, and best management practices and reported in peer reviewed journals [7]. While the model could prove its effective and reliable performance in other continents, its application results in Africa have high uncertainty [8].

There have been reviews of SWAT model applications that have been previously reported; for example, in comparison with other models [9-11]. The historical development and applications of the SWAT model (mainly in the United States of America (USA) and parts of Europe) were identified (for over 250 peer-reviewed and published articles) and reviewed by [4]. More than 20 peer-reviewed papers were identified and reviewed by describing SWAT model use in the Upper River Nile Basin (more than half of the papers were studies from Ethiopia) [6]. A total of 126 articles (since 2006) were identified and reviewed in South East Asia (with roughly 50\% of the studies conducted in Vietnam and Thailand) with an emphasis on model applications, current challenges, and future research directions [12]. Well over 100 SWAT studies were identified (published 1999-2015) from international journals, conference proceedings, thesis and dissertations, and reviewed in Brazil [13]. The aforementioned reviews mainly focused on applications such as model capability assessment, climate change assessment, land use/management, parameter and data input assessments, hydrology, and plant growth.

While acknowledging that the SWAT model has been applied in a wide array of studies globally, this paper review made an effort to condense and classify the SWAT applications into similar areas with the aforementioned review papers from around the globe, although some of these areas are closely related or overlap each other. The specific objectives of this review study are: (i) to summarize the key findings of SWAT applications in several studies in Africa, (ii) to analyze current challenges associated with SWAT model application in the African continent, and (iii) identify potential SWAT model improvements that can be applied in future research using the model in Africa.

\section{Overview of Reviewed Papers (Year, Journals, Countries, Data Sources and Funding)}

On 30 April 2019 a search of the term "SWAT" was conducted on the SWAT literature database (https: / / swat.tamu.edu/, accessed on 30 April 2019) and a total of over 3500 articles were displayed. The number of papers was narrowed down to 206 after selecting the articles that were conducted in Africa. The database contains peer-reviewed articles supported by the Centre for Agricultural and Rural Development (CARD). An overview of the methodological approach applied in this review is illustrated in Figure 1. 


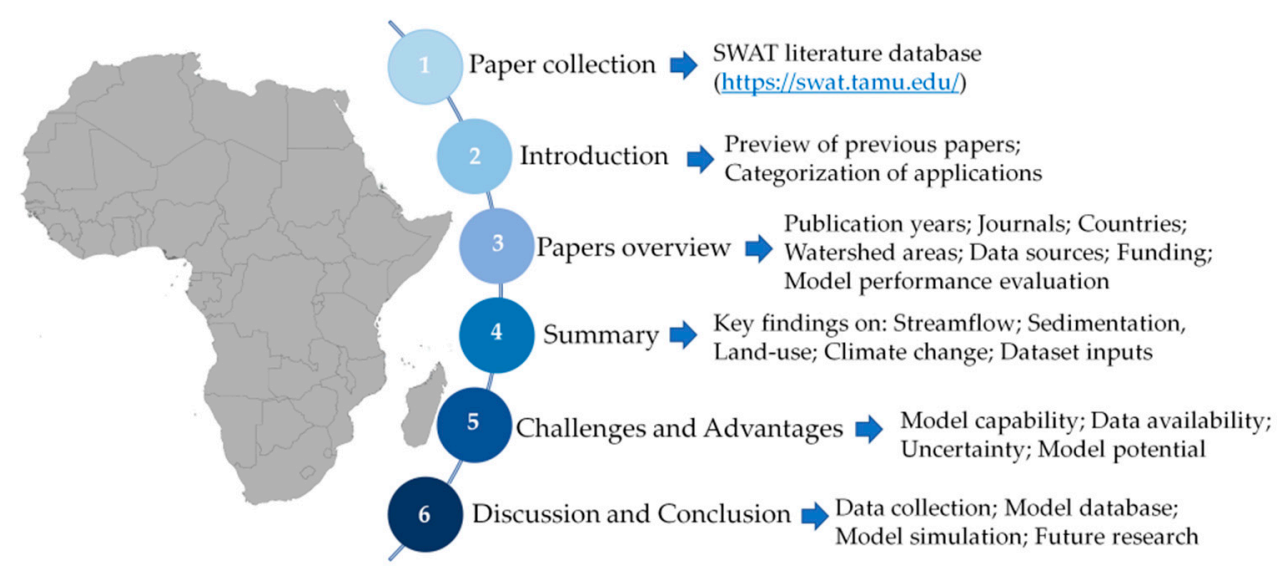

Figure 1. Methodological approach of the papers reviewed.

The papers reviewed extensively covered the African continent. The countries with the highest numbers of papers in this review were Ethiopia, Kenya, Tanzania, Tunisia, South Africa, and Nigeria with 69, 19, 15, 13, 13, and 7 papers respectively (Figure 2). From this total, $14.6 \%$ were regional studies, i.e., they were conducted in two or more countries.

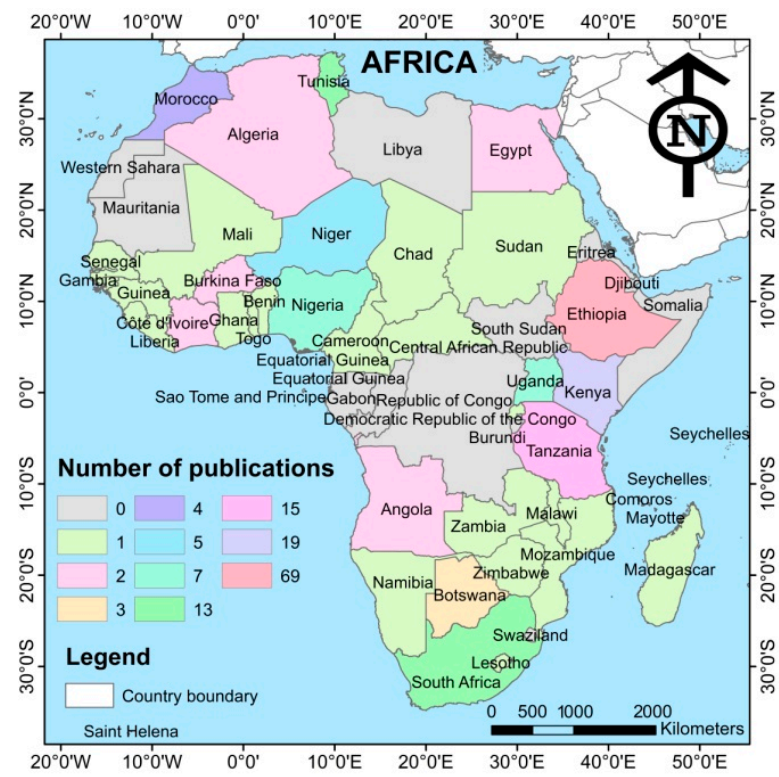

Figure 2. Relative distribution of reviewed papers by countries in Africa.

The papers reviewed in this study were published across 69 different journals. The journals with the highest numbers of studies were Hydrological Earth System Sciences $(10.2 \%)$, Water $(8.8 \%)$, Hydrological Processes $(6.8 \%)$, Science of the Total Environment (5.9\%), Agricultural Water Management (4.9\%), Journal of Hydrology (4.9\%), Physics and Chemistry of the Earth (4.4\%), Journal of Hydrology: Regional Studies (2.4\%), and Land Degradation and Development (2.4\%). About 18\% of the papers reviewed were published in a single journal; $12.7 \%$ in two journals; $7.3 \%$ in three journals; and $7.8 \%$ in four journals.

The papers reviewed were from the years 2005 to 2019. The years with the highest numbers of papers in this review were 2017 and 2018, with 30 papers each (Figure 3a). The areas of reviewed watersheds simulated using the SWAT model were mainly between $1000-5000 \mathrm{~km}^{2}$. There were six regional studies that covered over $500,000 \mathrm{~km}^{2}$, mainly in the Eastern, Southern, and Western Africa regions (Figure 3b). 


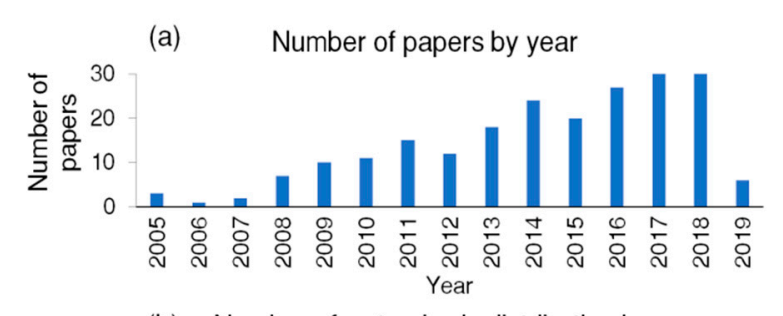

(b) Number of watersheds distribution by area

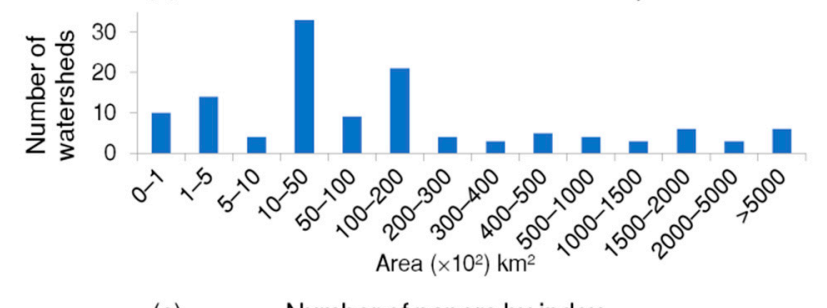

(c) Number of papers by index

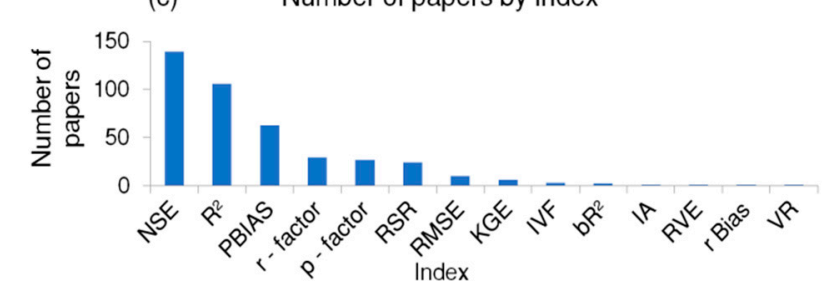

Figure 3. Number of papers by year, watershed distribution by area, and number of papers by index.

The performance/evaluation of the SWAT model outputs were assessed using several indices (Figure 3c). Nash-Sutcliffe efficiency (NSE), $\mathrm{R}^{2}$ (square of Pearson's product), and percent bias (PBIAS) were the most commonly used indices, with 139, 106, and 63 papers respectively. IA (index of agreement), RVE (relative volume error), $r$ bias (relative bias) and VR (volume ratio) were the least used, with one paper each. Others used were RMSE (root mean square error), RSR (a standardized RMSE), KGE (Kling Gupta efficiency), IVF (index of volumetric fit), and $\mathrm{bR}^{2}$ (a multiplication of the coefficient of determination by the coefficient of the regression line between measured and simulated data).

Land-use data sources were reported in 154 papers. The main sources of land-use data were Landsat/satellite sources (32\%), the Global Land Characterization (GLCC) database $(16 \%)$, data developed from local sources (21\%), and data from previous studies (8\%) (See Appendix A: Table A1). Soil data sources were reported in 150 papers. The most common sources of soil data were the Food and Agriculture Organization (FAO) soil database (40\%), a soil and terrain database $(16 \%)$, local sources $(14 \%)$, and data from previous studies $(13 \%)$ (See Appendix A: Table A2). A total of 148 of the papers reviewed reported their sources of digital elevation models (DEMs). Out of the 148, the most-used DEM sources were the Shuttle Radar Topography Mission (SRTM) - 32\%, the Advanced Spaceborne Thermal Emission and Reflection Radiometer (ASTER) - 24\%, the United States Geological Survey (USGS) - 12\%, and developed from previous studies-19\%. (See Appendix A: Table A3).

The funding sources were broadly reviewed based on the regions. The main funding sources for the reviewed studies were from institutes, governments, and universities in the European Union (EU)—at 47\%—and mainly in Switzerland, Germany, the United Kingdom, and Norway. Funding from African governments, agencies, and universities were second at $18 \%$, and third was funding from North America (mainly USA and Canada) at 13\% (Appendix A, Table A4). Collaborative funding, i.e., collaborations between institutes/organizations in Africa and others abroad was at 8\%, with funding from the Asian region at $6 \%$ (mainly China, South Korea, and Japan).

The review was broadly categorized into six summary sections, applications considering: water resources and streamflow, erosion- and sedimentation-related studies, land-use management and agricultural-related contexts, climate-change contexts, and parameterization and dataset inputs. 


\section{Summaries of SWAT Model Application}

\subsection{Applications Considering Water Resources and Streamflow Simulations}

Studies on water resources focused on extreme weather events (floods and droughts) research, rainfall-runoff modeling, streamflow modeling, and agriculture water use at various regional and national scales. The basins/catchments of the studies reviewed were mainly in the Eastern, Western, and Southern Africa regions (Figure 4). Some of the watersheds reviewed are part of large river basins; hence the extents of the large river basins are shown.

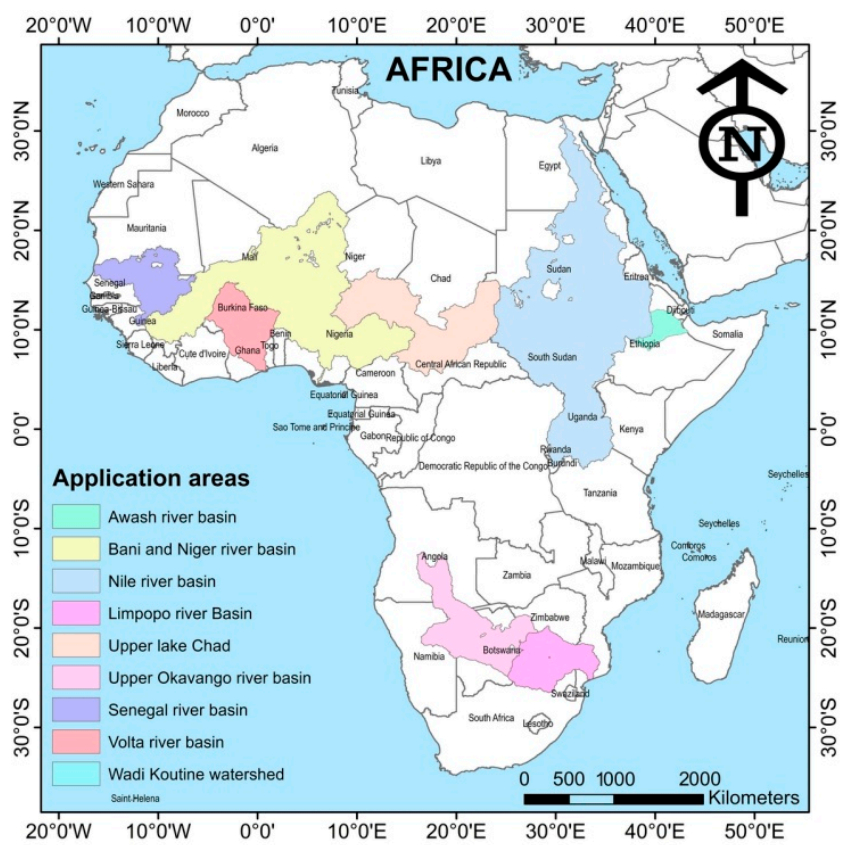

Figure 4. Application areas for studies reviewed considering water resources and streamflow simulations in Africa.

The SWAT model was assessed as being adequately capable in simulating streamflows in ungauged basins [14], analyzing runoff processes to contribute to water resources development [15], and calibration of the rainfall-runoff model using remotely sensed data [16].

The SWAT model has been applied to understand hydrological processes and responses in various river basins. The integration of climatic data inputs such as solar radiation, humidity, and wind can also improve the accuracy of the evapotranspiration estimation and therefore, the other water-balance components [17]. The hydrological water balance analysis of the Lake Tana Basin in Ethiopia indicated that base flow is an important component of the total discharge within the study area that contributes more than the surface runoff [18]. Radar rainfall data is useful in distributed hydrologic studies and was used as data input in the SWAT for application in flood analysis and prediction $[19,20]$, and in addressing model response to extreme weather events and improving water resources distribution [21].

The SWAT model was applied in studies of surface and groundwater resources and water availability. Studies were done on quantifying water resources for simulating the main hydrologic processes in arid environments [22], and examining groundwater (estimating the average annual modern recharge) in a sandstone aquifer in Northeast Africa [23]. Studies applying the SWAT model were done to characterize freshwater availability and scarcity for sustainable development [24], and estimate freshwater availability and related impacts on sustainable development $[25,26]$. On a continental scale, the SWAT was applied to quantify the freshwater availability for the whole African continent at a detailed subbasin level, and on a monthly basis with uncertainty analysis for 207 discharge stations, using only globally readily available data sets [27]. 


\subsection{Applications Considering Erosion and Sedimentation Related Studies}

Sedimentation studies using the SWAT model were done in several river basins across Africa on erosion and quantifying sediment yield. The extents of the river basins for the studies reviewed were mainly located in the Eastern Africa region. Similarly to Figure 4, the extents of the larger river basins are displayed (Figure 5).

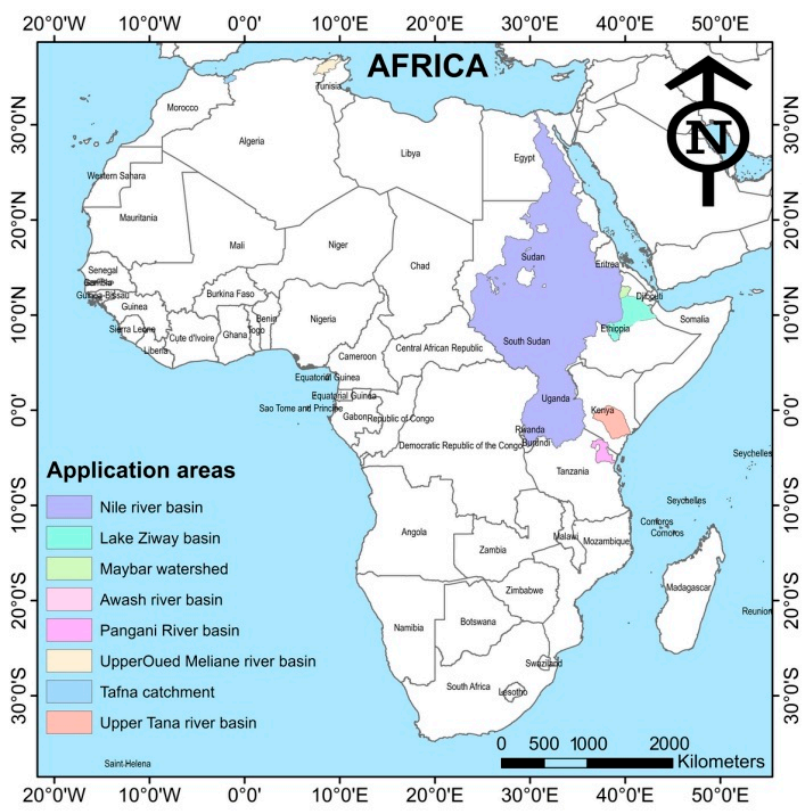

Figure 5. Application areas for studies reviewed considering erosion and sedimentation-related studies in Africa.

For a sustainable watershed management, the SWAT model was applied in examining changes in surface runoff generation and soil erosion in response to the land-use and land-cover (LULC) dynamics to delineate and prioritize soil erosion prone areas [28] and provide quantitative insight to the effectiveness of erosion control measures [29]. SWAT model applied in the Pangani River Basin was used to analyze catchments with dominant sheet erosion.

The SWAT model was applied in analyzing soil water conservation structures and their impacts on reducing runoff and erosion processes [30,31], as well as the relationship between soil conservation scenarios, slope length, and basin sediment yield [32]. Similar applications of soil conservation studies (e.g., implementing terraces and grassed waterways) were conducted and showed that structural conservation measures could reduce sediment yield from cultivated areas by more than $50 \%$ at the subcatchment level [33]. The SWAT model can be used for further analysis of different management scenarios for planning and implementing appropriate soil and water conservation strategies [34], and predicting surface runoff generation patterns and soil erosion hazards for prioritization of vulnerable areas over semi-arid catchments [35]. The SWAT model was demonstrated as a powerful tool in selecting the most technically effective management strategies in reducing soil degradation in a catchment [36].

A sediment management study using the SWAT showed that applying filter strips, stone bunds, and reforestation scenarios reduced the current sediment yields. However, a precise interpretation of the quantitative results may not be appropriate because some physical processes are not well-represented in the SWAT model [37]. Assessment of the impact of bench terraces on runoff and sediment yield in a Tunisian semi-arid region using the SWAT model indicated that the local terraces, established on approximately half of the watershed area, could reduce surface runoff and sediment yield [38]. The model was established as a better substitute for the sediment-rating curve and long-term sediment yield rate prediction, which can be done with reasonable accuracy [39]. The relationship 
between sediment deposition in dams and the life span of dams was conducted using the SWAT model; and the results used to evaluate the impact of the construction of dams in semi-arid catchments [40].

\subsection{Applications Considering Land Use Management and Agricultural Related Context}

Devising ecologically sound watershed management and development plans, and gaining insights into the implications of the present land-use management practices were achieved through applying the SWAT model to evaluate the impact of agricultural conservation practices on water and sediment yield [41]. Land-management practices such as the use of filter strips can reduce the annual evapotranspiration, and increase stream flow, as assessed using the SWAT model in the Ndembera river watershed in the Usangu basin [42]. Such land-management practices could have great potential to mitigate the impacts of land use/cover changes on water resource, thus increasing water resources availability.

The SWAT was used to analyze the degree of change in water yield by altering vegetation cover and demonstrate how afforestation in dry sub-basins can be used to offset afforestation pressure in wet sub-basins without altering the basin's water balance [43] The SWAT model simulated the impact of agroforestry on the water balance in the Mara River Basin (MRB) in East Africa, and the findings of this study could guide watershed managers on the level of trade-offs that might occur between reduced water yields and other benefits offered by agroforestry [44]. Analysis of the effects of deforestation on the availability of water for irrigation at the watershed level in the Upper Ouémé watershed in Benin showed that conservation of prevailing forests and woodlands is needed to allow the development of irrigation potential in the dry season depending on the scenario [45]. The SWAT model was used to analyze the sensitivity of the daily flow to changes in land use (conversion of part of the forest cover to agriculture), where it was deduced that a reduction in rainfall translates to a reduction in annual flow [46]. A combination of SWAT modelling and cost-based valuation was used to assess to what extent the presence of forests and woodlands regulates water availability throughout the year in two major African cities (Dar es Salaam and Morogoro) [47].

Changes in land cover were conducted using the SWAT model by analyzing historical land-cover trends to establish the relationship between land-cover changes and surface runoff patterns in the Upper Shire River basin, Malawi [48], and water yield in the Olifants Basin, South Africa [49]. Analysis of the land-use/land-cover changes on hydrological components demonstrated the impact on hydrological balance (as a result of transition from the vegetation to nonvegetation cover [50], and transition from woodland to cultivated land [51]); and on water-balance components in a tropical inland valley catchment based on various land-management scenarios [52]. Anthropogenic factors such as population growth, land policy changes, and deforestation can also pose as sustainability challenges on land and water uses and be major driving forces behind LULC changes and the impact of water resources as studied in the Lake Ziway watershed, Ethiopia [53].

Studies on agricultural activities' impacts on the hydrological cycle were conducted using the SWAT to provide more insights into management of water resources. The impacts of agricultural conservation practices such as contour farming, grass strips, and filter strips on sediment and water yield were simulated using the SWAT model to demonstrate the relationship between sediment reduction and filter strip widths [54]. Analysis of the impacts of infield rainwater harvesting (IRWH) and future agricultural expansion during land- and water-use change (LWUC) on the hydrologic cycle in the Wami River basin (Tanzania) indicated that LWUC caused huge changes in ET, the soil water content, percolation, and the streamflow from the river basin [55].

The SWAT model study by Welderufael [56] on the impact of rainwater harvesting on the water resources of the Modder River Basin in the central region of South Africa revealed that conventional agricultural land-use types generated the highest direct flows compared to the ones dominated by pasture and IRWH land-use types. The SWAT model was applied in irrigation studies related to nutrient application and supplemental water demands 
in smallholder agriculture $[57,58]$. Irrigation studies using the SWAT also evaluated the potential of expanding small-scale irrigation in Nigeria and Sub-Saharan Africa $[47,59]$ and analysis of irrigation development trends in relation to water-balance components and river discharges [60]. Agricultural practices such crop systems, fertilization, manure deposition, and tillage can change the infiltration and runoff characteristics of the land surface, which could in turn influence sediment yield [61,62].

\subsection{Applications Considering a Climate Change Context}

The SWAT model was used to assess potential future climatic changes and how they might affect water resources. The studies reviewed areas such as covered water resources management, water access, and agriculture (Figure 6).

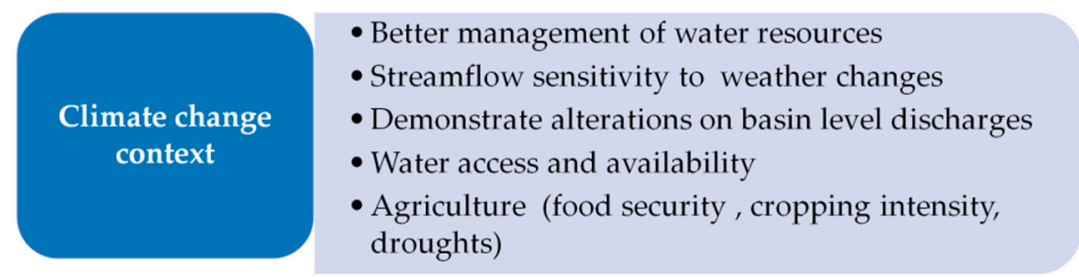

Figure 6. Applications considering a climate context.

The results were used to enhance understanding of the impacts of various climatic change scenarios and better management and development of water resources in the Nzoia catchment, Kenya [63]; and to highlight the importance of the precipitation-evaporation balance in the River Mitano basin, Uganda [64]. Increased rainfall and warmer temperatures over the coming decades, as modelled by SWAT, are likely to put a tremendous pressure on the hydrological system of the Keleta River watershed in Ethiopia [65]. Studies on the effect of climate change on future streamflow using the SWAT model in the Dinder River Basin (DRB), Sudan, indicated that the projected streamflow is quite sensitive to rainfall and temperature variation [66]. SWAT model analysis with bias corrected and downscaled Intergovernmental Panel on Climate Change (IPCC) coupled model intercomparison Project 5 (CMIP5) climate data was used to demonstrate alterations on basin level discharges [67].

An in-depth analysis of results based on SWAT simulations using the HadCM3 global circulation model (GCM) climate scenarios assessed annual river discharge in the Upper Nile Basin and highlighted an urgent need for improved understanding of projected climate change impacts on water resources [68]. Estimations of an increase in projected precipitation in the Upper Blue Nile basin (using multiple GCMs' projections and multiple hydrological models) were reported by [69]. The hydrologic implications of climate change on the water resources of the Nile River showed that, averaged over eleven GCMs, the Nile River is expected to experience an increase in streamflow early in the period (2010-2039), due to generally increased precipitation [70]. Similarly, investigations of the impact of future climate scenarios on the hydrology of the Mara River Basin showed a significant increase in the flow volume of the Mara River [71] and possible future challenges in water access and availability in the East African Pangani Basin [72].

The impact of climate change on the potential for increasing rain-fed cropping intensity through sequential cropping and irrigation expansion in central Benin was analyzed using the SWAT, and the results highlighted the need for planned development that need to be overcome to improve food security in the coming decades [73]. SWAT model simulations were performed based on the traditional and the rainfed, bunded rice-cultivation systems to analyze the sensitivities of hydrological processes to projected climate changes under rice intensification in three watersheds in Benin, revealing projected increases in surface runoff and decreases in water yield in the future [74].

A study on the mid-term impact of climate change on water resources in Africa at a sub-basin spatial and monthly temporal scale was quantified using the SWAT model. The 
results had a relatively high confidence in the projections as it was established that in many regions/countries, most of the climate scenarios projected the same direction of changes in water resources. The study results suggested an increase in the number of dry days and the frequency of their occurrences suggested an increase in the drought events and their duration in the future, which would pose an additional challenge to the agriculture in dry regions where water shortage is already severe, while irrigation is expected to become more important to stabilize and increase food production [27].

\subsection{Applications Considering Model Parameterization and Dataset Inputs}

The applications reviewed in this section covered areas such as basin scale calibration, evaluating water yield and simulations with rain-gauge and global rainfall data (Figure 7).

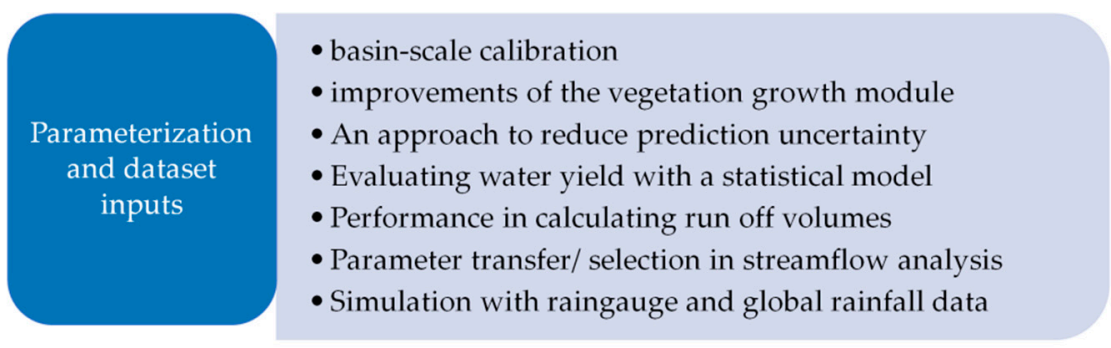

Figure 7. Applications considering model parameterization and dataset inputs.

The SWAT model was applied in a topographic-index-based method to describe and test the distribution of effective soil water-holding capacity among hydraulic response units (HRUs), and present an approach to utilize easily available topographic and soil information to systematically calibrate a complex basin-scale model without explicitly optimizing model results to measured streamflow [75]. The structural improvements of the vegetation growth module of SWAT for simulating the vegetation variables-such as the leaf area index (LAI) - for tropical ecosystems was demonstrated by comparing uncalibrated SWAT model simulations of the LAI using the modified (i.e., SWAT-T) and the standard SWAT vegetation growth module [76]. Additional constraints were used to constrain the SWAT model in the Wami River basin and evaluated an approach to reduce equifinality and prediction uncertainty; concluding that using additional constraints is a progression towards more credible and reliable predictions using the SWAT model [77].

The SWAT model was applied in a multidimensional methodology study with the partial least square regression (PLSR) statistical model to evaluate water yield, surface runoff, and base flow [78]. A CN-free version of the SWAT model was developed based on a simple water balance approach which revealed that the SWAT performs better in saturation-excess-controlled areas when a simple saturation-deficit water balance model is used to calculate runoff volumes [79]. The applicability of the curve number (CN) method within the SWAT model was used to estimate surface runoff at the watershed scale in tropical regions. The $\mathrm{CN}$ method generally performed well in simulating surface runoff at high rainfall intensity and underestimated surface runoff at low rainfall intensity [80].

The parameter transfer technique within the SWAT model was used to capture streamflow amounts, and streamflow variability produced better results at the monitoring site of the calibrated watershed [81]. Selection of parameters in the SWAT model directly influences the process representation in the model; thus, proper care must be taken in selecting an appropriate parameter set for simulating the different water-balance components [82].

SWAT model was used to compare the performance of climate forecast system reanalysis (CFSR) weather with that of conventional weather in simulating observed streamflow, and showed that the water-balance components were higher in the CFSR weather simulations than the conventional weather simulations [83]. The use of CFSR weather data as SWAT inputs was established as the better alternative with which to simulate streamflow, given the limitations of conventional weather data [84]. Where weather stations do not have full datasets, a WXGEN (weather generator) can provide an option for estimating 
weather variables or to extend measurements to other simulation periods with fragmented information [85].

SWAT model simulations for streamflow were poor with rainfall gauge station data but improved significantly with the CFSR and climate hazards group infrared precipitation with station (CHIRPS) datasets for the Nzoia Basin, Western Kenya. The CHIRPS dataset, in comparison with the CFSR dataset provided an improved statistical performance after model calibration [86]. Similar studies showed that CFSR-derived weather data can be reliably used as input data instead of traditional weather station data in simulating discharge from a watershed $[87,88]$. For data-scarce regions, or for regions with weather stations containing inaccurate or missing data, it is more reasonable to use generated daily data from more accurate monthly statistics, which are now available from the Climatic Research Unit [89]. Bias correction of satellite rainfall estimates significantly improves the SWAT model simulations as highlighted in the hydrological modeling of a small mountainous watershed in Ethiopia [90].

Mountain environments are complex, and applying a multidisciplinary approach for data inputs in modeling mountainous and high-altitude regions could contribute to improving SWAT model performance. This was applied in the High Atlas in Morocco in studying hydrological processes with scarce data where remote sensing was used in snow surfaces identification [91]. SWAT model accuracy performance was greatly affected by spatial rainfall variability in the mountainous Mediterranean watershed in Tunisia; and use of more rainfall gauges as input data may not necessarily lead to more accurate predictions in the SWAT [92].

\section{Challenges and Advantages of the SWAT Model Application}

Several challenges were reported in the SWAT studies analyzed in this review. The challenges included data availability/data gaps, data quality, and model limitations. The SWAT model could not capture the dynamics of sediment load delivery in some seasons at a catchment outlet, compounding the insufficient capability of SWAT to simulate the process dynamics in small catchments [39]. Sufficient and accurate data is required to calibrate and validate streamflow and sediment dynamics in order to improve plausibility for SWAT model simulations [41]. Inherently poor spatial correlation of datasets was reported as a likely source of relatively poor performance of the SWAT model in streamflow simulation [86]. The model, compared to other watershed models to predict hydrologic response, could not simulate the increasing runoff ratio from almost zero in the beginning of the rainfall season to over $50 \%$ later in the rainy phase and under-predicted the runoff for a vast majority of rainfall events. This was attributed to the curve number method in the SWAT, which assumes a relationship between rainfall and discharge, as modeled in the Lake Tana basin [93].

The SWAT model's performance has been described as less reliable than other models, as the river routing function in the model is not suited for the identification of deposition and erosion as studied in the Simiyu River watershed in Tanzania. For this reason, SOBEK-RE (1D Hydrodynamic Simulation Software for Rivers and Estuaries) software was described as better software for more detailed studies of lowland rivers where data is available and morphological predictions are required [94]. Limited detailed rainfall data availability and the lack of information on reservoir management affected the SWAT model's performance, hence the recommendation to collect data at a higher frequency use, i.e., sub-daily rainfall data instead of daily rainfall as modeled in the Medjerda River basin in Tunisia [95].

Roux [96] concluded that their results indicated the loads to hypothetical land-use change, reflecting the spatial connectivity within the catchment was due to the retention of loads mainly in the channel and farm dams. A consideration of using the SWAT model in simulating sediments is giving sufficient attention to different connectivity aspects in sediment migration modelling, together with the way a model accounts for these aspects at different scales and from source to sink. While assessing the impacts of land-cover changes 
on the hydrological cycle, dynamics between the changes and effects of land use/land cover and climate on each other are not modelled, i.e., one entity is modelled as the other is held constant and this does not reflect what happens in reality [48]. Land-use maps with low spatial data quality are associated with high uncertainties [61].

Data availability/gaps were reported in several studies. These data limitations related to lack of images for LULC analysis, weather, sediment, soils, discharge records, and reservoir management $[35,95,97]$. Limitations were also reported that related to coarse spatial and low temporal resolution of the data $[15,63,98]$. On the other hand, obtaining data by field surveys would take a long time and considerable human resources [99].

Uncertainties were reported in SWAT simulations. On a continental scale, limited and unevenly distributed rain gauges and discharge stations with varying time series lengths were associated with large prediction uncertainties [27]. Although efforts have been made to reduce and quantify model uncertainty by using the SUFI-2 algorithm for calibration, Notter [72] reported that their SWAT simulation results remained affected by uncertainty in input data, model structure, and the assumptions made for future scenarios. Similar uncertainties were reported with the scenarios data and the model structural errors [61,72].

The SWAT model was reported to underpredict the runoff for a vast majority of rainfall events. This was directly related to the curve number method in the SWAT, which assumes a relationship between rainfall and discharge, independent of the stage of the rain phase [37]. The hydrograph of observed and simulated monthly streamflow after SWAT model calibration showed inconsistency in prediction of streamflow peaks as simulated in the lower Aswa basin, in Northern Uganda [100]. Inability to capture peaks in simulations was also recorded in a SWAT study conducted for assessing water availability for competing uses in Lesotho [101].

The requirement of leaf area index to compute the potential transpiration, the potential soil evaporation, the plant biomass, and the determination of daily potential plant transpiration were cited as limitations of the annual vegetation growth cycle in the standard SWAT model growth module, which could also influence the simulation of the transpiration [76]. A recommendation for improving SWAT model performance in crop growth and production studies is the need to develop local crop-growth parameters as highlighted in the modeling of water harvesting systems in the arid South of Tunisia [22]. Other limitations in the SWAT model were reported as a difficulty in simulating outflow from wetlands and an inadequacy with the original SWAT reservoir model [102].

In their simulation results of high percolation rates from predominant shallow and sandy textured soils, Ouessar [22] attributed this to the disadvantage of SWAT forcing all precipitation that does not run off to enter the soil profile. A main disadvantage of the SWAT model was outlined as it models many processes, and hence has hundreds of parameters and requires many data that make the calibration process tedious. Limited data in the sub-soil physical properties, such as soil texture, soil hydraulic conductivity, and soil water holding capacity, which have major influences on simulating lateral and groundwater flow components $[47,56]$.

As a deterministic model, each successive model run in the SWAT using the same inputs will produce the same outputs, which isolates the hydrologic response to changes in a single variable, such as land-use change, and the non-stationarity of the model accounts for variation through time [41].

Despite the challenges and limitations, several advantages of the SWAT model were mentioned, hence its selection by many researchers for hydrological uses. A review of 16 well-known (continental scale) hydrological and land surface models revealed that the SWAT model has a higher potential and suitability for hydrological drought forecasting in Africa; in addition to its ability to be applied in a simpler way with few parameters, despite having high data requirements [103]. A study comparing hydrological models for the assessment of water resources in a data-scarce region in the Upper Blue Nile River Basin deduced that the SWAT model was better for the simulation of midrange, dry, and low flows in the Ribb watershed [104]. Martine [43] selected the SWAT model for its relatively 
low data input requirements, and its ability to generate missing weather records during simulation or fill in gaps in weather records. Data availability emerged as a major challenge in a significant number of the papers reviewed. The SWAT model is suitable for large-scale applications, and it is easily applicable in data-scarce areas [4]; and in addition to the aforementioned explanations, many researchers in government organizations, universities, and research institutes selected the SWAT over other models in their research/studies.

The SWAT model was demonstrated as a capable of predicting flow and sediment yields and performing further analyses of hydrological responses [105]. In sedimentation simulation, the SWAT model was observed as a better substitute of the sediment-rating curve, which allowed for long-term sediment yield rate prediction to be done with reasonable accuracy [106]. The SWAT model's accuracy can also be useful for understanding the impact of sediment transport on the water storage capacity of dams in a semi-arid region [40], and evaluating the hydrological impacts of soil and water conservation [107]. The model was also justified as being able to capture watershed-scale responses caused by the differences in the watershed characteristics and used to demonstrate that in seemingly similar paired watersheds, a difference in soils can significantly affect the hydrologic responses of the watersheds [108].

The SWAT model was able to generate good spatial and temporal simulations of flow throughout the Upper Olifants catchment, South Africa, implying that the model can be highly beneficial in supporting catchment management through identification of drivers (i.e., point source over non-point source pollution) and specific source areas (i.e., sub-catchments) responsible for high ortho-phosphate loading [109].

For poorly gauged rural catchments with limited data, the SWAT model can be set up and calibrated because of the present technology (satellite-based) of estimating rainfall and temperature values. The model could provide dependable results for the stakeholders for planning and management purposes as observed in a West African study [110]. Even accounting for uncertainties in data inputs, the SWAT model produced satisfactory results and proved to be a flexible and reliable tool for simulating the impact of agricultural management on hydrological behavior [111].

The SWAT model was demonstrated as having good potential for applications in hydrologic/water quality; flood disaster risk management; evaluating the cost and benefits of adopting best management practices (BMPs) for sediment control $[19,112]$ as a decision support tool (DST) in evaluating the impacts of land use changes [49]; and in drought planning and mitigation in data-scarce regions [113]. All these applications were recommended for watershed management. An important asset of SWAT is its ability to simulate crop production and management processes, thus allowing the estimation of water productivity and economic evaluation of alternative water-management scenarios [22].

\section{Discussion}

Data availability was reported as a challenge in a significant number of the studies reviewed. Several studies reported low temporal and spatial data quality as a challenge, especially in studies related to land-use assessments. A major push supporting improved data collection and analysis is required for agricultural development in Africa. Efforts to improve statistical data in Africa such as the Accelerated Data Program for Africa (ADP) should be supported by national governments to improve the quality of future simulations [114]. Future studies using the SWAT model would require good spatial and temporal data in order to make more detailed assessments, conclusions, and reduce uncertainty. Also, SWAT modelers should make an effort to avail themselves of sufficient data to allow more thorough reviews and future analysis by other modelers. The recently developed SWAT+ could be improved by morphing its model parameterization data into databases [115]. Obtaining additional data could contribute to expanding the SWAT+ database with data from different parts of the world, which could consequently reduce the model's setup and parameterization efforts. 
The SWAT model has demonstrated its ability to simulate water quality and can be used in future planning and management in agriculture. The previous SWAT model, however, limited the number of constituents that could be routed at the same time and had no simulation of salt. SWAT+ has a definition of suites that could be simulated for each object; and allows for simulation of salt as a constituent-thus, allowing for more comprehensive simulation of constituents and routing of more than one pesticide at the same time. Future studies could apply SWAT+ simulations on nutrient transport, non-point pollutions, and nutrient concentrations in water resources to support decision-making in water resources. Population growth rates in Africa are expected to increase in the upcoming decades. Sub-Saharan Africa's population is projected to double by 2050 [116], which will present challenges to the achievement of the United Nations' Sustainable Development Goal 2 of combating hunger and malnutrition. The common agricultural foods largely consumed in Africa as staple foods are cereals (corn, wheat), pulses (beans), and root tubers (cassava, potatoes) [117]. The increasing demand for these foods will be accompanied by a corresponding increase in agricultural activities. Future simulations could lay more emphasis on water quality for agriculture to promote sustainable agricultural practices. Governments should be strongly encouraged to invest in water-quality monitoring in rivers and watersheds, particularly in agriculture-intensive areas. Improved data availability could reduce uncertainties and increase reliability of SWAT simulations.

In the East African region, greater investment in agricultural research and expanded irrigation is needed to counter the effects of climate change [118]. In the previous SWAT model, placements of reservoirs were on main channels at sub-basin outlets; there were no pumps, canals, animal herds, or water rights objects, and the number of crops growing at the same time was limited to one. The recent SWAT+ allows for placement of reservoirs anywhere in the watershed; and pumps, canals, water rights, and animal herds are defined as spatial objects and an unlimited number of crops can be grown at the same time [115]. These improvements allow for consideration of anthropogenic water assessment. Future studies could apply SWAT + to create more simulations that highlight future water availability for agriculture and other purposes. Simulations on water availability can provide an overview of the actual water resource status and help to identify regions where in-depth analysis may be necessary [119]. This would be important in developing frameworks for regional and national infrastructure development in the agricultural sector.

In Africa's Albertine Rift region (comprising Uganda, Tanzania, Burundi, Rwanda, The Democratic Republic of Congo, and Zambia) national population change was established as the strongest driver of forest loss in these countries [120]. Population increase could result in human settlements encroaching in forested areas, which could influence soil erosion, water resources, and reduction in forest cover. The SWAT model has been applied in previous studies to highlight the relationship between deforestation, sedimentation, and soil erosion. The model subdivides sub basins into HRUs and defines water areas as HRUs. SWAT+ allows for separation of water and land areas (e.g., forests) and defines the water areas as ponds/reservoirs [115]; allowing for improved simulation of the landscape processes. Future research could apply this improvement for better analysis of environmental processes and integrate the population growth aspect and related socio-economic issues for better understanding the ecosystem.

\section{Conclusions}

As the African population continues to burgeon, the impact on the environmental resources (particularly water and forest cover) is likely to increase. A multidimensional approach will be needed to analyze, forecast, and propose effective management practices in order to conserve the ecosystem. For example, research areas should be broadened to nutrient transport and water resources pollution analysis in the environment, and to encompass anthropogenic aspects. Coupling SWAT with other models can provide a strong basis for a multidimensional approach. Research studies should also focus on aligning scientific studies with local, national, and regional policies. Research outputs 
should highlight changes, trends, and related impacts by taking into account established environmental thresholds at the local and regional levels, e.g., allowable environmental flows in rivers, recommended forest cover in countries, and allowable thresholds for pollutants in the environment. Such analyses will provide a strong scientific contribution to developing national and regional environmental policies.

Obtaining additional data to be used for future research will provide an important avenue for other researchers to conduct further studies; for example, to journals as supplementary material. This will allow for a more stringent evaluation of the model results. The further studies could be based on recommendations/conclusions from the previous research studies and enable the research studies to have continuity and refrain from being isolated studies with no follow-ups. Data availability from local sources for modeling is comparatively low; and many researchers opt to use global data in their analyses. This could be a main reason why the studies reviewed mainly centered on water resources, sedimentation, and land-use management, as some of the data required for such studies can be obtained from global datasets. Governments should be encouraged to channel more resources into research (particularly local data collection) that can be used to address/incorporate/adopt integrated watershed management and related environmental areas, of which SWAT has proven competence to conduct. Researchers in government institutes, universities, and other academic institutions should take the opportunity to utilize SWAT and the recently developed SWAT + in their various research works for planning and management of the wider ecosystem, and development of policies.

Author Contributions: G.A. (Conceptualization, Investigation, Methodology, Software, Validation, Formal analysis, Writing-original draft preparation), T.H.L. (Methodology, Software, Validation, Formal Analysis), T.G. (Conceptualization, Resources, Supervision, Writing-review and editing), T.K. (Conceptualization, Resources, Supervision, Writing-review and editing). All authors have read and agreed to the published version of the manuscript.

Funding: This work was supported by JSPS KEKENHI Grant Number JP20KK0242 and JP18H02295.

Institutional Review Board Statement: Not applicable.

Informed Consent Statement: Not applicable.

Acknowledgments: The authors would like to acknowledge the support from Tokyo University of Agriculture and Technology, Japan. The researchers would also like to thank the anonymous reviewers whose comments significantly improved this paper.

Conflicts of Interest: The authors declare no conflict of interest.

Appendix A

Table A1. Land use data sources.

\begin{tabular}{cc}
\hline Data Source & Number \\
Landsat/satellite sources & 54 \\
Own development/local sources & 35 \\
Global Land Cover Characterization (GLCC) database & 27 \\
Derived from previous studies & 13 \\
Food and Agriculture Organization Africover land cover dataset & 12 \\
Water and Land Resource Centre (WLRC) & 2 \\
Soil Conservation Research Programme (SCRP) & 2 \\
International Soil Reference and Information Centre (ISRIC) & 2 \\
Agriculture Research Council - Institute of Soil, Climate and Water & 1 \\
Moderate Resolution Imaging Spectro-radiometer (MODIS) & 1 \\
IMPETUS database 250 m resolution & 1 \\
Centre for Mapping and Remote Sensing & 1 \\
International Livestock Research Institute (ILRI) & 1 \\
Climate Change Initiative Land Cover (CCI-LC) & 1 \\
\hline
\end{tabular}


Table A2. Soil data sources.

\begin{tabular}{cc}
\hline Data Source & Number \\
\hline FAO soil data base & 66 \\
Soil and Terrain Database & 27 \\
Local sources & 23 \\
Derived from previous studies & 21 \\
Harmonized Digital Soil map of the World (HWSD) & 9 \\
WaterBase & 1 \\
IRD (French National Research Institute for Sustainable Development) & 1 \\
Soil and Water Conservation Agency from Landsat Thematic Mapper & 1 \\
International Soil Reference and Information Centre & 1 \\
\hline
\end{tabular}

Table A3. Digital Elevation Model (DEM) data sources.

\begin{tabular}{cc}
\hline Data Source & Number \\
\hline Shuttle Radar Topography Mission (SRTM) & 52 \\
Developed from previous studies/own sources/local & 31 \\
Advanced Space borne Thermal Emission and Reflection Radiometer (ASTER) & 24 \\
United States Geological Survey (USGS) & 20 \\
HydroSHEDS & 7 \\
CGIAR Consortium for Spatial Information website & 6 \\
SPOT-5/6 (Satellite Pour l'Observation de la Terre) DEM & 3 \\
Japan Aerospace Exploration Agency (JAXA) & 2 \\
International Water Management Institute (IWMI) & 1 \\
Institute of Soil, Climate and Water (ISCW) & 1 \\
\hline
\end{tabular}

Table A4. Funding sources.

\begin{tabular}{cc}
\hline Source & Number \\
\hline International Funding (European Union) & 67 \\
African/Continental & 25 \\
International Funding (North America) & 18 \\
Collaborative funding & 11 \\
International funding (Asia) & 8 \\
\hline
\end{tabular}

\section{References}

1. Krysanova, V.; White, M. Advances in Water Resources Assessment with SWAT-An Overview. Hydrol. Sci. J. 2015, 60, 1-13. [CrossRef]

2. Zhang, S.; Al-Asadi, K. Evaluating the Effect of Numerical Schemes on Hydrological Simulations: HYMOD as A Case Study. Water 2019, 11, 329. [CrossRef]

3. Arnold, J.G.; Srinivasan, R.; Muttiah, R.S.; Williams, J.R. Large Area Hydrologic Modeling and Assessment Part I: Model Development. J. Am. Water Resour. Assoc. 1998, 34, 73-89. [CrossRef]

4. Gassman, P.; Reyes, M.; Green, C.; Arnold, J. The Soil and Water Assessment Tool: Historical Development, Applications, and Future Research Directions. Trans. ASAE 2007, 50, 1211-1250. [CrossRef]

5. Mutenyo, I.; Nejadhashemi, P.A.; Woznicki, S.A.; Giri, S. Evaluation of Swat Performance on a Mountainous Watershed in Tropical Africa. Hydrol. Curr. Res. 2013, S14, 1-7. [CrossRef]

6. Van Griensven, A.; Ndomba, P.; Yalew, S.; Kilonzo, F. Critical Review of SWAT Applications in the Upper Nile Basin Countries. Hydrol. Earth Syst. Sci. 2012, 16, 3371-3381. [CrossRef]

7. CARD SWAT Literature Database 2019. Available online: https://www.card.iastate.edu/swat_articles/readme/ (accessed on 31 July 2019).

8. Gassman, P.W.; Sadeghi, A.M.; Srinivasan, R. Applications of the SWAT Model Special Section: Overview and Insights. J. Environ. Qual. 2014, 43, 1. [CrossRef]

9. Arnold, J.G.; Fohrer, N. SWAT2000: Current Capabilities and Research Opportunities in Applied Watershed Modelling. Hydrol. Process. 2005, 19, 563-572. [CrossRef]

10. Borah, D.K.; Bera, M. Watershed-Scale Hydrologic and Nonpoint-Source Pollution Models: Review of Applications. Trans. ASAE 2004, 47, 789-803. [CrossRef] 
11. Harper, D.M.; Brierley, B.; Ferguson, A.J.D.; Phillips, G. The Ecological Bases for Lake and Reservoir Management. In Proceedings of the Ecological Bases for Management of Lakes and Reservoirs Symposium, Leicester, UK, 19-22 March 1996; Springer Science \& Business Media: Berlin, Germany, 2013. ISBN 978-94-017-3282-6.

12. Tan, M.L.; Gassman, P.W.; Srinivasan, R.; Arnold, J.G.; Yang, X. A Review of SWAT Studies in Southeast Asia: Applications, Challenges and Future Directions. Water 2019, 11, 914. [CrossRef]

13. de Almeida Bressiani, D.; Gassman, P.W.; Fernandes, J.G.; Garbossa, L.H.P.; Srinivasan, R.; Bonumá, N.B.; Mendiondo, E.M. Review of Soil and Water Assessment Tool (SWAT) Applications in Brazil: Challenges and Prospects. Int. J. Agric. Biol. Eng. 2015, 8, 9-35. [CrossRef]

14. Chaibou Begou, J.; Jomaa, S.; Benabdallah, S.; Bazie, P.; Afouda, A.; Rode, M. Multi-Site Validation of the SWAT Model on the Bani Catchment: Model Performance and Predictive Uncertainty. Water 2016, 8, 178. [CrossRef]

15. Dessie, M.; Verhoest, N.E.C.; Pauwels, V.R.N.; Admasu, T.; Poesen, J.; Adgo, E.; Deckers, J.; Nyssen, J. Analyzing Runoff Processes through Conceptual Hydrological Modeling in the Upper Blue Nile Basin, Ethiopia. Hydrol. Earth Syst. Sci. 2014, 18, $5149-5167$. [CrossRef]

16. Milzow, C.; Krogh, P.E.; Bauer-Gottwein, P. Combining Satellite Radar Altimetry, SAR Surface Soil Moisture and GRACE Total Storage Changes for Hydrological Model Calibration in a Large Poorly Gauged Catchment. Hydrol. Earth Syst. Sci. 2011, 15, 1729-1743. [CrossRef]

17. Nkiaka, E.; Nawaz, N.R.; Lovett, J.C. Evaluating Global Reanalysis Datasets as Input for Hydrological Modelling in the SudanoSahel Region. Hydrology 2017, 4, 13. [CrossRef]

18. Setegn, S.G.; Srinivasan, R.; Melesse, A.M.; Dargahi, B. SWAT Model Application and Prediction Uncertainty Analysis in the Lake Tana Basin, Ethiopia. Hydrol. Process. 2010, 24, 357-367. [CrossRef]

19. Jayakrishnan, R.; Srinivasan, R.; Santhi, C.; Arnold, J.G. Advances in the Application of the SWAT Model for Water Resources Management. Hydrol. Process. 2005, 19, 749-762. [CrossRef]

20. Kehew, A.E.; Milewski, A.; Soliman, F. Reconstructing an Extreme Flood from Boulder Transport and Rainfall-Runoff Modelling: Wadi Isla, South Sinai, Egypt. Glob. Planet. Chang. 2010, 70, 64-75. [CrossRef]

21. Adeba, D.; Kansal, M.L.; Sen, S. Economic Evaluation of the Proposed Alternatives of Inter-Basin Water Transfer from the Baro Akobo to Awash Basin in Ethiopia. Sustain. Water Resour. Manag. 2016, 2, 313-330. [CrossRef]

22. Ouessar, M.; Bruggeman, A.; Abdelli, F.; Mohtar, R.H.; Gabriels, D.; Cornelis, W.M. Modelling Water-Harvesting Systems in the Arid South of Tunisia Using SWAT. Hydrol. Earth Syst. Sci. 2009, 13, 2003-2021. [CrossRef]

23. Sultan, M.; Metwally, S.; Milewski, A.; Becker, D.; Ahmed, M.; Sauck, W.; Soliman, F.; Sturchio, N.; Yan, E.; Rashed, M.; et al Modern Recharge to Fossil Aquifers: Geochemical, Geophysical, and Modeling Constraints. J. Hydrol. 2011, 403, 14-24. [CrossRef]

24. Mosase, E.; Ahiablame, L.; Srinivasan, R. Spatial and Temporal Distribution of Blue Water in the Limpopo River Basin, Southern Africa: A Case Study. Ecohydrol. Hydrobiol. 2019, 19, 252-265. [CrossRef]

25. Adeba, D.; Kansal, M.; Sen, S. Assessment of Water Scarcity and Its Impacts on Sustainable Development in Awash Basin, Ethiopia. Sustain. Water Resour. Manag. 2015, 1. [CrossRef]

26. Schuol, J.; Abbaspour, K.C.; Srinivasan, R.; Yang, H. Estimation of Freshwater Availability in the West African Sub-Continent Using the SWAT Hydrologic Model. J. Hydrol. 2008, 352, 30-49. [CrossRef]

27. Faramarzi, M.; Abbaspour, K.C.; Ashraf Vaghefi, S.; Farzaneh, M.R.; Zehnder, A.J.B.; Srinivasan, R.; Yang, H. Modeling Impacts of Climate Change on Freshwater Availability in Africa. J. Hydrol. 2013, 480, 85-101. [CrossRef]

28. Gessesse, B.; Bewket, W.; Bräuning, A. Model-Based Characterization and Monitoring of Runoff and Soil Erosion in Response to Land Use/Land Cover Changes in the Modjo Watershed, Ethiopia. Land Degrad. Dev. 2015, 26, 711-724. [CrossRef]

29. Hunink, J.E.; Niadas, I.A.; Antonaropoulos, P.; Droogers, P.; de Vente, J. Targeting of Intervention Areas to Reduce Reservoir Sedimentation in the Tana Catchment (Kenya) Using SWAT. Hydrol. Sci. J. 2013, 58, 600-614. [CrossRef]

30. Melaku, N.D.; Renschler, C.S.; Holzmann, H.; Strohmeier, S.; Bayu, W.; Zucca, C.; Ziadat, F.; Klik, A. Prediction of Soil and Water Conservation Structure Impacts on Runoff and Erosion Processes Using SWAT Model in the Northern Ethiopian Highlands. J. Soils Sediments 2018, 18, 1743-1755. [CrossRef]

31. Lemann, T.; Zeleke, G.; Amsler, C.; Giovanoli, L.; Suter, H.; Roth, V. Modelling the Effect of Soil and Water Conservation on Discharge and Sediment Yield in the Upper Blue Nile Basin, Ethiopia. Appl. Geogr. 2016, 73, 89-101. [CrossRef]

32. Aga, A.O.; Chane, B.; Melesse, A.M. Soil Erosion Modelling and Risk Assessment in Data Scarce Rift Valley Lake Regions, Ethiopia. Water 2018, 10, 1684. [CrossRef]

33. Gathagu, J.N.; Sang, J.K.; Maina, C.W. Modelling the Impacts of Structural Conservation Measures on Sediment and Water Yield in Thika-Chania Catchment, Kenya. Int. Soil Water Conserv. Res. 2018, 6, 165-174. [CrossRef]

34. Yesuf, H.M.; Assen, M.; Alamirew, T.; Melesse, A.M. Modeling of Sediment Yield in Maybar Gauged Watershed Using SWAT, Northeast Ethiopia. CATENA 2015, 127, 191-205. [CrossRef]

35. Mosbahi, M.; Benabdallah, S.; Boussema, R. Assessment of Soil Erosion Risk Using SWAT Model. Arab. J. Geosci. 2012, 6. [CrossRef]

36. Tesfahunegn, G.B.; Vlek, P.L.G.; Tamene, L. Management Strategies for Reducing Soil Degradation through Modeling in a GIS Environment in Northern Ethiopia Catchment. Nutr. Cycl. Agroecosystems 2012, 92, 255-272. [CrossRef]

37. Betrie, G.D.; Mohamed, Y.A.; van Griensven, A.; Srinivasan, R. Sediment Management Modelling in the Blue Nile Basin Using SWAT Model. Hydrol. Earth Syst. Sci. 2011, 15, 807-818. [CrossRef] 
38. Khelifa, W.B.; Hermassi, T.; Strohmeier, S.; Zucca, C.; Ziadat, F.; Boufaroua, M.; Habaieb, H. Parameterization of the Effect of Bench Terraces on Runoff and Sediment Yield by Swat Modeling in a Small Semi-Arid Watershed in Northern Tunisia. Land Degrad. Dev. 2017, 28, 1568-1578. [CrossRef]

39. Ndomba, P.; Mtalo, F.; Killingtveit, Å. A Guided SWAT Model Application on Sediment Yield Modeling in Pangani River Basin: Lessons Learnt. J. Urban Environ. Eng. 2008, 2, 53-62. [CrossRef]

40. Zettam, A.; Taleb, A.; Sauvage, S.; Boithias, L.; Belaidi, N.; Sánchez-Pérez, J.M. Modelling Hydrology and Sediment Transport in a Semi-Arid and Anthropized Catchment Using the SWAT Model: The Case of the Tafna River (Northwest Algeria). Water 2017, 9 , 216. [CrossRef]

41. Mwangi, J.; Shisanya, C.; Gathenya, J.; Namirembe, S.; Moriasi, D. A Modeling Approach to Evaluate the Impact of Conservation Practices on Water and Sediment Yield in Sasumua Watershed, Kenya. J. Soil Water Conserv. 2015, 70, 75-90. [CrossRef]

42. Hyandye, C.; Worqlul, A.; Martz, L.; Muzuka, A. The Impact of Future Climate and Land Use/Cover Change on Water Resources in the Ndembera Watershed and Their Mitigation and Adaptation Strategies. Environ. Syst. Res. 2018, 7. [CrossRef]

43. Martine, N.; D’Urso, G.; Immerzeel, W.W. Adaptive Simulation of the Impact of Changes in Land Use on Water Resources in the Lower Aswa Basin. J. Agric. Eng. 2013, 43, 159-164. [CrossRef]

44. Mwangi, H.M.; Julich, S.; Patil, S.D.; McDonald, M.A.; Feger, K.-H. Modelling the Impact of Agroforestry on Hydrology of Mara River Basin in East Africa. Hydrol. Process. 2016, 30, 3139-3155. [CrossRef]

45. Duku, C.; Zwart, S.J.; Hein, L. Modelling the Forest and Woodland-Irrigation Nexus in Tropical Africa: A Case Study in Benin. Agric. Ecosyst. Environ. 2016, 230, 105-115. [CrossRef]

46. Melesse, A.M.; McClain, M.; Wang, X.; Abira, M.; Mutayoba, W. Modeling the Impact of Land-Cover and Rainfall Regime Change Scenarios on the Flow of Mara River, Kenya. World Environ. Water Resour. Congr. 2008, 1-10. [CrossRef]

47. Xie, H.; You, L.; Takeshima, H. Invest in Small-Scale Irrigated Agriculture: A National Assessment on Potential to Expand Small-Scale Irrigation in Nigeria. Agric. Water Manag. 2017, 193, 251-264. [CrossRef]

48. GITHUI, F.; Mutua, F.; Bauwens, W. Estimating the Impacts of Land-Cover Change on Runoff Using the Soil and Water Assessment Tool (SWAT): Case Study of Nzoia Catchment, Kenya. Hydrol. Sci. J. 2009, 54, 899-908. [CrossRef]

49. Gyamfi, C.; Ndambuki, J.M.; Salim, R.W. Hydrological Responses to Land Use/Cover Changes in the Olifants Basin, South Africa. Water 2016, 8, 588. [CrossRef]

50. Gashaw, T.; Tulu, T.; Argaw, M.; Worqlul, A.W. Modeling the Hydrological Impacts of Land Use/Land Cover Changes in the Andassa Watershed, Blue Nile Basin, Ethiopia. Sci. Total Environ. 2018, 619-620, 1394-1408. [CrossRef] [PubMed]

51. Woldesenbet, T.A.; Elagib, N.A.; Ribbe, L.; Heinrich, J. Hydrological Responses to Land Use/Cover Changes in the Source Region of the Upper Blue Nile Basin, Ethiopia. Sci. Total Environ. 2017, 575, 724-741. [CrossRef] [PubMed]

52. Gabiri, G.; Leemhuis, C.; Diekkrüger, B.; Näschen, K.; Steinbach, S.; Thonfeld, F. Modelling the Impact of Land Use Management on Water Resources in a Tropical Inland Valley Catchment of Central Uganda, East Africa. Sci. Total Environ. 2019, 653, 1052-1066. [CrossRef]

53. Desta, H.; Lemma, B.; Gebremariam, E. Identifying Sustainability Challenges on Land and Water Uses: The Case of Lake Ziway Watershed, Ethiopia. Appl. Geogr. 2017, 88, 130-143. [CrossRef]

54. Gathagu, J.N.; Mourad, K.A.; Sang, J. Effectiveness of Contour Farming and Filter Strips on Ecosystem Services. Water 2018, 10, 1312. [CrossRef]

55. Wambura, F.J.; Dietrich, O.; Graef, F. Analysis of Infield Rainwater Harvesting and Land Use Change Impacts on the Hydrologic Cycle in the Wami River Basin. Agric. Water Manag. 2018, 203, 124-137. [CrossRef]

56. Welderufael, W.A.; Woyessa, Y.E.; Edossa, D.C. Impact of Rainwater Harvesting on Water Resources of the Modder River Basin, Central Region of South Africa. Agric. Water Manag. 2013, 116, 218-227. [CrossRef]

57. Dile, Y.T.; Karlberg, L.; Daggupati, P.; Srinivasan, R.; Wiberg, D.; Rockström, J. Assessing the Implications of Water Harvesting Intensification on Upstream-Downstream Ecosystem Services: A Case Study in the Lake Tana Basin. Sci. Total Environ. 2016, 542, 22-35. [CrossRef]

58. Andersson, J.; Zehnder, A.; Jewitt, G.; Yang, H. Water Availability, Demand and Reliability of In Situ Water Harvesting in Smallholder Rain-Fed Agriculture in the Thukela River Basin, South Africa. Hydrol. Earth Syst. Sci. 2009, 13. [CrossRef]

59. Xie, H.; You, L.; Wielgosz, B.; Ringler, C. Estimating the Potential for Expanding Smallholder Irrigation in Sub-Saharan Africa. Agric. Water Manag. 2013. [CrossRef]

60. Desta, H.; Lemma, B. SWAT Based Hydrological Assessment and Characterization of Lake Ziway Sub-Watersheds, Ethiopia. J. Hydrol. Reg. Stud. 2017, 13, 122-137. [CrossRef]

61. Bossa, A.Y.; Diekkrüger, B.; Giertz, S.; Steup, G.; Sintondji, L.O.; Agbossou, E.K.; Hiepe, C. Modeling the Effects of Crop Patterns and Management Scenarios on N and P Loads to Surface Water and Groundwater in a Semi-Humid Catchment (West Africa). Agric. Water Manag. 2012, 115, 20-37. [CrossRef]

62. Ayele, G.T.; Teshale, E.Z.; Yu, B.; Rutherfurd, I.D.; Jeong, J. Streamflow and Sediment Yield Prediction for Watershed Prioritization in the Upper Blue Nile River Basin, Ethiopia. Water 2017, 9, 782. [CrossRef]

63. Githui, F.; Gitau, W.; Mutua, F.; Bauwens, W. Climate Change Impact on SWAT Simulated Streamflow in Western Kenya. Int. J. Climatol. 2009, 29, 1823-1834. [CrossRef]

64. Kingston, D.; Taylor, R. Projected Impacts of Climate Change on Groundwater and Stormflow in a Humid, Tropical Catchment in the Ugandan Upper Nile Basin. Hydrol. Earth Syst. Sci. Discuss. 2010, 7. [CrossRef] 
65. Bekele, D.; Alamirew, T.; Kebede, A.; Zeleke, G.; Melesse, A.M. Modeling Climate Change Impact on the Hydrology of Keleta Watershed in the Awash River Basin, Ethiopia. Environ. Model. Assess. 2019, 24, 95-107. [CrossRef]

66. Basheer, A.; Lü, H.; Omer, A.; Ali, A.; Abdelgader, A. Impacts of Climate Change under CMIP5 RCP Scenarios on the Streamflow in the Dinder River and Ecosystem Habitats in Dinder National Park, Sudan. Hydrol. Earth Syst. Sci. Discuss. 2015, 12, 10157-10195. [CrossRef]

67. Wagena, M.B.; Sommerlot, A.; Abiy, A.Z.; Collick, A.S.; Langan, S.; Fuka, D.R.; Easton, Z.M. Climate Change in the Blue Nile Basin Ethiopia: Implications for Water Resources and Sediment Transport. Clim. Chang. 2016, 139, 229-243. [CrossRef]

68. Kingston, D.G.; Taylor, R.G. Sources of Uncertainty in Climate Change Impacts on River Discharge and Groundwater in a Headwater Catchment of the Upper Nile Basin, Uganda. Hydrol. Earth Syst. Sci. 2010, 14, 1297-1308. [CrossRef]

69. Teklesadik, A.D.; Alemayehu, T.; van Griensven, A.; Kumar, R.; Liersch, S.; Eisner, S.; Tecklenburg, J.; Ewunte, S.; Wang, X. InterModel Comparison of Hydrological Impacts of Climate Change on the Upper Blue Nile Basin Using Ensemble of Hydrological Models and Global Climate Models. Clim. Chang. 2017, 141, 517-532. [CrossRef]

70. Beyene, T.; Lettenmaier, D.; Kabat, P. Hydrologic Impacts of Climate Change on the Nile River Basin: Implications of the 2007 IPCC Scenarios. Clim. Chang. 2006, 100, 433-461. [CrossRef]

71. Dessu, S.; Melesse, A. Impact and Uncertainties of Climate Change on the Hydrology of the Mara River Basin, Kenya/Tanzania. Hydrol. Process. 2012, 27. [CrossRef]

72. Notter, B.; Hurni, H.; Wiesmann, U.; Ngana, J. Evaluating Watershed Service Availability under Future Management and Climate Change Scenarios in the Pangani Basin. Phys. Chem. Earth Parts ABC 2013, 61-62,1-11. [CrossRef]

73. Duku, C.; Zwart, S.J.; Hein, L. Impacts of Climate Change on Cropping Patterns in a Tropical, Sub-Humid Watershed. PLoS ONE 2018, 13, e0192642. [CrossRef] [PubMed]

74. Danvi, A.; Giertz, S.; Zwart, S.J.; Diekkrüger, B. Rice Intensification in a Changing Environment: Impact on Water Availability in Inland Valley Landscapes in Benin. Water 2018, 10, 74. [CrossRef]

75. Easton, Z.M.; Walter, M.T.; Fuka, D.R.; White, E.D.; Steenhuis, T.S. A Simple Concept for Calibrating Runoff Thresholds in Quasi-Distributed Variable Source Area Watershed Models. Hydrol. Process. 2011, 25, 3131-3143. [CrossRef]

76. Alemayehu, T.; Griensven, A.v.; Woldegiorgis, B.T.; Bauwens, W. An Improved SWAT Vegetation Growth Module and Its Evaluation for Four Tropical Ecosystems. Hydrol. Earth Syst. Sci. 2017, 21, 4449-4467. [CrossRef]

77. Wambura, F.J.; Dietrich, O.; Lischeid, G. Improving a Distributed Hydrological Model Using Evapotranspiration-Related Boundary Conditions as Additional Constraints in a Data-Scarce River Basin. Hydrol. Process. 2018, 32, 759-775. [CrossRef]

78. Aladejana, O.O.; Salami, A.T.; Adetoro, O.-I.O. Hydrological Responses to Land Degradation in the Northwest Benin Owena River Basin, Nigeria. J. Environ. Manag. 2018, 225, 300-312. [CrossRef] [PubMed]

79. White, E.D.; Easton, Z.M.; Fuka, D.R.; Collick, A.S.; Adgo, E.; McCartney, M.; Awulachew, S.B.; Selassie, Y.G.; Steenhuis, T.S. Development and Application of a Physically Based Landscape Water Balance in the SWAT Model. Hydrol. Process. 2011, 25, 915-925. [CrossRef]

80. Dile, Y.; Karlberg, L.; Srinivasan, R.; Rockström, J. Investigation of the Curve Number Method for Surface Runoff Estimation In Tropical Regions. JAWRA J. Am. Water Resour. Assoc. 2016, 52. [CrossRef]

81. Roth, V.; Nigussie, T.K.; Lemann, T. Model Parameter Transfer for Streamflow and Sediment Loss Prediction with SWAT in a Tropical Watershed. Environ. Earth Sci. 2016, 75, 1321. [CrossRef]

82. Tessema, S.M.; Lyon, S.W.; Setegn, S.G.; Mörtberg, U. Effects of Different Retention Parameter Estimation Methods on the Prediction of Surface Runoff Using the SCS Curve Number Method. Water Resour. Manag. 2014, 28, 3241-3254. [CrossRef]

83. Dile, Y.T.; Srinivasan, R. Evaluation of CFSR Climate Data for Hydrologic Prediction in Data-Scarce Watersheds: An Application in the Blue Nile River Basin. JAWRA J. Am. Water Resour. Assoc. 2014, 50, 1226-1241. [CrossRef]

84. Tolera, M.B.; Chung, I.-M.; Chang, S.W. Evaluation of the Climate Forecast System Reanalysis Weather Data for Watershed Modeling in Upper Awash Basin, Ethiopia. Water 2018, 10, 725. [CrossRef]

85. Aouissi, J.; Benabdallah, S.; Lili Chabaâne, Z.; Cudennec, C. Evaluation of Potential Evapotranspiration Assessment Methods for Hydrological Modelling with SWAT-Application in Data-Scarce Rural Tunisia. Agric. Water Manag. 2016, 174, 39-51. [CrossRef]

86. Le, A.M.; Pricope, N.G. Increasing the Accuracy of Runoff and Streamflow Simulation in the Nzoia Basin, Western Kenya, through the Incorporation of Satellite-Derived CHIRPS Data. Water 2017, 9, 114. [CrossRef]

87. Fuka, D.R.; Walter, M.T.; MacAlister, C.; Degaetano, A.T.; Steenhuis, T.S.; Easton, Z.M. Using the Climate Forecast System Reanalysis as Weather Input Data for Watershed Models. Hydrol. Process. 2014, 28, 5613-5623. [CrossRef]

88. Duan, Z.; Tuo, Y.; Liu, J.; Gao, H.; Song, X.; Zhang, Z.; Yang, L.; Mekonnen, D.F. Hydrological Evaluation of Open-Access Precipitation and Air Temperature Datasets Using SWAT in a Poorly Gauged Basin in Ethiopia. J. Hydrol. 2019, 569, 612-626. [CrossRef]

89. Schuol, J.; Abbaspour, K.C. Using Monthly Weather Statistics to Generate Daily Data in a SWAT Model Application to West Africa. Ecol. Model. 2007, 201, 301-311. [CrossRef]

90. Bitew, M.M.; Gebremichael, M.; Ghebremichael, L.T.; Bayissa, Y.A. Evaluation of High-Resolution Satellite Rainfall Products through Streamflow Simulation in a Hydrological Modeling of a Small Mountainous Watershed in Ethiopia. J. Hydrometeorol. 2012, 13, 338-350. [CrossRef]

91. Chaponnière, A.; Boulet, G.; Chehbouni, A.; Aresmouk, M. Understanding Hydrological Processes with Scarce Data in a Mountain Environment. Hydrol. Process. 2008, 22, 1908-1921. [CrossRef] 
92. Aouissi, J.; Benabdallah, S.; Lili Chabaâne, Z.; Cudennec, C. Valuing Scarce Observation of Rainfall Variability with Flexible SemiDistributed Hydrological Modelling-Mountainous Mediterranean Context. Sci. Total Environ. 2018, 643, 346-356. [CrossRef]

93. Moges, M.; Schmitter, P.; Tilahun, S.; Langan, S.; Dagnew, D.; Tadesse, A.; Steenhuis, T. Suitability of Watershed Models to Predict Distributed Hydrologic Response in the Awramba Watershed in Lake Tana Basin. Land Degrad. Dev. 2016. [CrossRef]

94. van Griensven, A.; Popescu, I.; Abdelhamid, M.R.; Ndomba, P.M.; Beevers, L.; Betrie, G.D. Comparison of Sediment Transport Computations Using Hydrodynamic versus Hydrologic Models in the Simiyu River in Tanzania. Phys. Chem. Earth Parts ABC 2013, 61-62, 12-21. [CrossRef]

95. Bouraoui, F.; Benabdallah, S.; Jrad, A.; Bidoglio, G. Application of the SWAT Model on the Medjerda River Basin (Tunisia). Phys. Chem. Earth Parts ABC 2005, 30, 497-507. [CrossRef]

96. Roux, J.J.L.; Sumner, P.D.; Lorentz, S.A.; Germishuyse, T. Connectivity Aspects in Sediment Migration Modelling Using the Soil and Water Assessment Tool. Geosciences 2013, 3, 1-12.

97. Näschen, K.; Diekkrüger, B.; Leemhuis, C.; Seregina, L.; van der Linden, R. Impact of Climate Change on Water Resources in the Kilombero Catchment in Tanzania. Water 2019, 11, 859. [CrossRef]

98. Duku, C.; Rathjens, H.; Zwart, S.J.; Hein, L. Towards Ecosystem Accounting: A Comprehensive Approach to Modelling Multiple Hydrological Ecosystem Services. Hydrol. Earth Syst. Sci. 2015, 19, 4377-4396. [CrossRef]

99. Tibebe, D.; Bewket, W. Surface Runoff and Soil Erosion Estimation Using the SWAT Model in the Keleta Watershed, Ethiopia. Land Degrad. Dev. 2011, 22, 551-564. [CrossRef]

100. Nyeko, M. Hydrologic Modelling of Data Scarce Basin with SWAT Model: Capabilities and Limitations. Water Resour. Manag. 2015, 29, 81-94. [CrossRef]

101. Maliehe, M.; Mulungu, D.M.M. Assessment of Water Availability for Competing Uses Using SWAT and WEAP in South Phuthiatsana Catchment, Lesotho. Phys. Chem. Earth Parts ABC 2017, 100, 305-316. [CrossRef]

102. Cohen Liechti, T.; Matos, J.; Ferras, D.; Boillat, J.-L.; Schleiss, A. Hydrological Modelling of the Zambezi River Basin Taking into Account Floodplain Behaviour by a Modified Reservoir Approach. Int. J. River Basin Manag. 2014, 12, 29-41. [CrossRef]

103. Trambauer, P.; Maskey, S.; Winsemius, H.; Werner, M.; Uhlenbrook, S. A Review of Continental Scale Hydrological Models and Their Suitability for Drought Forecasting in (Sub-Saharan) Africa. Phys. Chem. Earth Parts ABC 2013, 66, 16-26. [CrossRef]

104. Tegegne, G.; Park, D.K.; Kim, Y.-O. Comparison of Hydrological Models for the Assessment of Water Resources in a Data-Scarce Region, the Upper Blue Nile River Basin. J. Hydrol. Reg. Stud. 2017, 14, 49-66. [CrossRef]

105. Mtibaa, S.; Hotta, N.; Irie, M. Analysis of the Efficacy and Cost-Effectiveness of Best Management Practices for Controlling Sediment Yield: A Case Study of the Joumine Watershed, Tunisia. Sci. Total Environ. 2018, 616-617, 1-16. [CrossRef] [PubMed]

106. Gosling, S.N.; Zaherpour, J.; Mount, N.J.; Hattermann, F.F.; Dankers, R.; Arheimer, B.; Breuer, L.; Ding, J.; Haddeland, I.; Kumar, R.; et al. A Comparison of Changes in River Runoff from Multiple Global and Catchment-Scale Hydrological Models under Global Warming Scenarios of $1{ }^{\circ} \mathrm{C}, 2^{\circ} \mathrm{C}$ and $3{ }^{\circ} \mathrm{C}$. Clim. Chang. 2017, 141, 577-595. [CrossRef]

107. Ben Salah, N.C.; Abida, H. Runoff and Sediment Yield Modeling Using SWAT Model: Case of Wadi Hatab Basin, Central Tunisia. Arab. J. Geosci. 2016, 9, 579. [CrossRef]

108. Worqlul, A.W.; Ayana, E.K.; Yen, H.; Jeong, J.; MacAlister, C.; Taylor, R.; Gerik, T.J.; Steenhuis, T.S. Evaluating Hydrologic Responses to Soil Characteristics Using SWAT Model in a Paired-Watersheds in the Upper Blue Nile Basin. CATENA 2018, 163, 332-341. [CrossRef]

109. Dabrowski, J. Applying SWAT to Predict Ortho-Phosphate Loads and Trophic Status in Four Reservoirs in the Upper Olifants Catchment, South Africa. Hydrol. Earth Syst. Sci. 2014, 18. [CrossRef]

110. Awotwi, A.; Yeboah, F.; Kumi, M. Assessing the Impact of Land Cover Changes on Water Balance Components of White Volta Basin in West Africa. Water Environ. J. 2015, 29, 259-267. [CrossRef]

111. Danvi, A.; Giertz, S.; Zwart, S.J.; Diekkrüger, B. Comparing Water Quantity and Quality in Three Inland Valley Watersheds with Different Levels of Agricultural Development in Central Benin. Agric. Water Manag. 2017, 192, 257-270. [CrossRef]

112. Briak, H.; Moussadek, R.; Aboumaria, K.; Mrabet, R. Assessing Sediment Yield in Kalaya Gauged Watershed (Northern Morocco) Using GIS and SWAT Model. Int. Soil Water Conserv. Res. 2016, 4, 177-185. [CrossRef]

113. Lweendo, M.K.; Lu, B.; Wang, M.; Zhang, H.; Xu, W. Characterization of Droughts in Humid Subtropical Region, Upper Kafue River Basin (Southern Africa). Water 2017, 9, 242. [CrossRef]

114. Kelly, V.; Donovan, C. Agricultural Statistics in Sub-Saharan Africa: Differences in Institutional Arrangements and Their Impacts on Agricultural Statistics Systems. A Synthesis of Four Country Case Studies; Michigan State University, Department of Agricultural Economics: East Lansing, MI, USA, 2008. [CrossRef]

115. Bieger, K.; Arnold, J.G.; Rathjens, H.; White, M.J.; Bosch, D.D.; Allen, P.M.; Volk, M.; Srinivasan, R. Introduction to SWAT+, A Completely Restructured Version of the Soil and Water Assessment Tool. JAWRA J. Am. Water Resour. Assoc. 2017, 53, 115-130. [CrossRef]

116. The Population Division of the Department of Economic and Social Affairs. World Population Prospects Highlights, 2019 Revision Highlights, 2019 Revision; United Nations: New York, NY, USA, 2019; ISBN 978-92-1-148316-1.

117. Agriculture Food and Nutrition for Africa-A Resource Book for Teachers of Agriculture. Available online: http://www.fao.org/ 3/w0078e/w0078e00.htm\#TopOfPage (accessed on 25 October 2020).

118. Research Institute (IFPRI). East African Agriculture and Climate Change a Comprehensive Analysis; International Food Policy Research Institute: Washington, DC, USA, 2013. 
119. Schuol, J.; Abbaspour, K.C.; Yang, H.; Srinivasan, R.; Zehnder, A.J.B. Modeling Blue and Green Water Availability in Africa. Water Resour. Res. 2008, 44. [CrossRef]

120. Ryan, S.J.; Palace, M.W.; Hartter, J.; Diem, J.E.; Chapman, C.A.; Southworth, J. Population pressure and global markets drive a decade of forest cover change in Africa's Albertine Rift. Appl. Geogr. 2017, 81, 52-59. [CrossRef] 